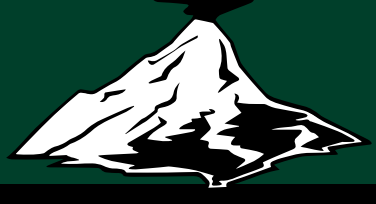

\title{
Overview for Geologic Field-Trip Guides to Mount Mazama, Crater Lake Caldera, and Newberry Volcano, Oregon
}
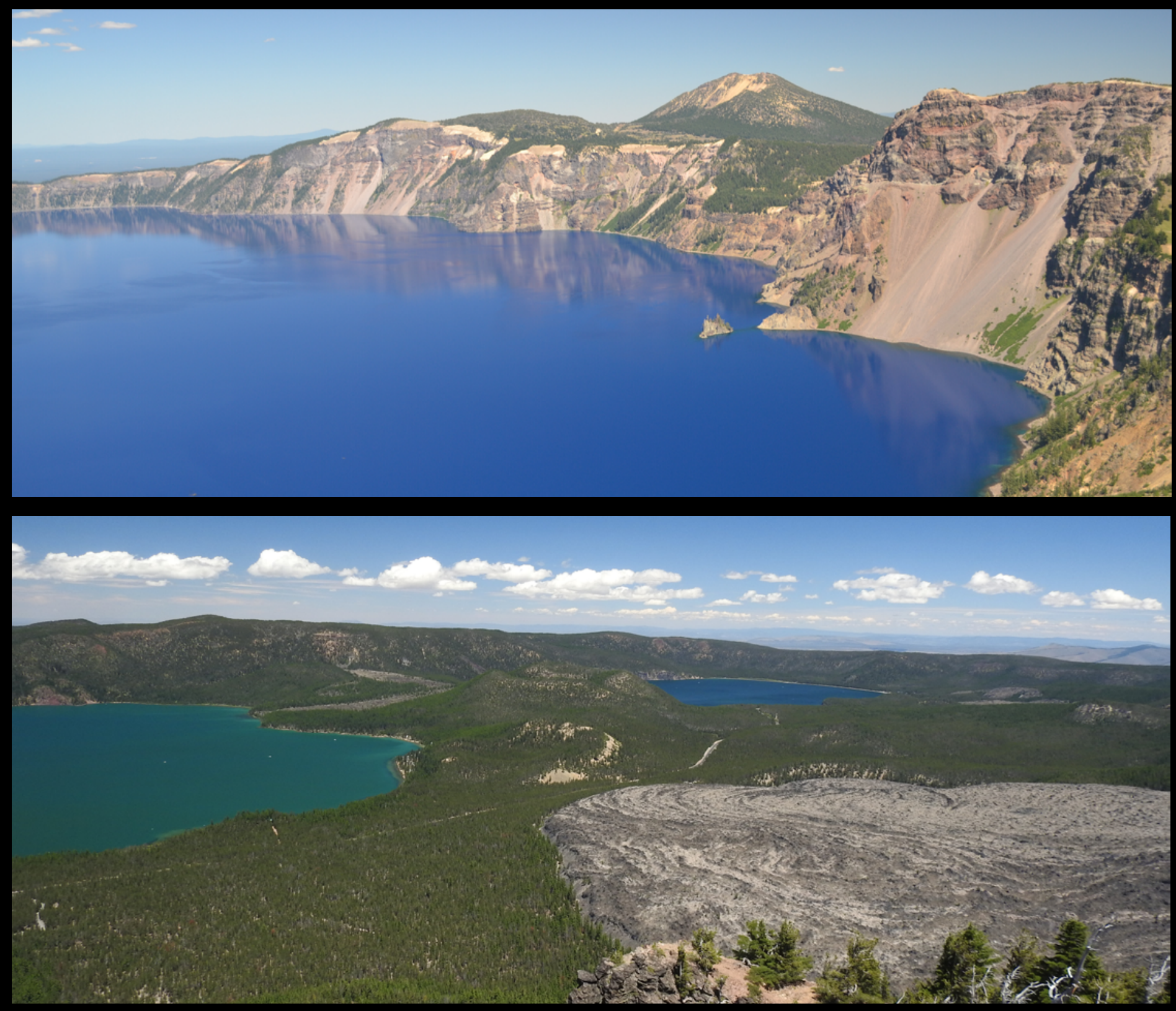

Scientific Investigations Report 2017-5022-J 
Cover (top photo): View east-northeast from Garfield Peak on the south rim of Crater Lake caldera. Peak on skyline is 8,929 feet $(2,722$ meters) Mount Scott, an $\sim 420$ thousand years before present $(\mathrm{ka})$ dacite stratovolcano considered to be part of Mount Mazama, the volcano that collapsed during the caldera-forming eruption $\sim 7,700$ years ago. The caldera walls in this view expose Mazama lava flows and fragmental deposits from as old as $\sim 400 \mathrm{ka}$ at Phantom Cone, adjacent to tiny Phantom Ship island, to as young as $\sim 27 \mathrm{ka}$ at Redcloud Cliff, the V-shaped face at the top of the wall left of center. The beheaded glacial valley of Kerr Notch, the low point on the caldera rim, is seen between Phantom Ship and Mount Scott. Photograph by Carly McLanahan.

Cover (bottom photo): Newberry Volcano, Oregon, is the largest volcano in the Cascades volcanic arc. This north-facing view taken from the volcano's peak, Paulina Peak (elevation 7,984 feet), encompasses much of the volcano's 4-by-5-milewide central caldera, a volcanic depression formed in a powerful explosive eruption about 75,000 years ago. The caldera's two lakes, Paulina Lake (left) and the slightly higher East Lake (right), are fed in part by active hot springs heated by molten rock (magma) deep beneath the caldera. The Central Pumice Cone sits between the lakes. The mostly treeless, 1,300-year-old Big Obsidian Flow, youngest lava flow on the volcano, is surrounded by forest south of the lakes. Photograph by Robert Jensen. 


\section{Overview for Geologic Field-Trip Guides to Mount Mazama, Crater Lake Caldera, and Newberry Volcano, Oregon}

By Charles R. Bacon, Julie M. Donnelly-Nolan, Robert A. Jensen, and Heather M. Wright

Scientific Investigations Report 2017-5022-J 


\title{
U.S. Department of the Interior \\ RYAN K. ZINKE, Secretary
}

\section{U.S. Geological Survey William H. Werkheiser, Acting Director}

\author{
U.S. Geological Survey, Reston, Virginia: 2017
}

For more information on the USGS — the Federal source for science about the Earth, its natural and living resources, natural hazards, and the environment-visit https://www.usgs.gov or call 1-888-ASK-USGS.

For an overview of USGS information products, including maps, imagery, and publications, visit https://store.usgs.gov.

Any use of trade, firm, or product names is for descriptive purposes only and does not imply endorsement by the U.S. Government.

Although this information product largely is in the public domain, it may also contain copyrighted materials as noted in the text. Permission to reproduce copyrighted items must be secured from the copyright owner.

Suggested citations:

Bacon, C.R., Donnelly-Nolan, J.M., Jensen, R.A., and Wright, H.M., 2017, Overview for Geologic Field-Trip Guides to Mount Mazama, Crater Lake Caldera, and Newberry Volcano, Oregon: U.S. Geological Survey Scientific Investigations Report 2017-5022-J, 3 p., https://doi.org/10.3133/sir20175022J.

ISSN 2328-0328 (online) 


\section{Preface}

The North American Cordillera is home to a greater diversity of volcanic provinces than any comparably sized region in the world. The interplay between changing plate-margin interactions, tectonic complexity, intra-crustal magma differentiation, and mantle melting have resulted in a wealth of volcanic landscapes. Field trips in this series visit many of these landscapes, including (1) active subduction-related arc volcanoes in the Cascade Range; (2) flood basalts of the Columbia Plateau; (3) bimodal volcanism of the Snake River Plain-Yellowstone volcanic system; (4) some of the world's largest known ignimbrites from southern Utah, central Colorado, and northern Nevada; (5) extension-related volcanism in the Rio Grande Rift and Basin and Range Province; and (6) the spectacular eastern Sierra Nevada featuring Long Valley Caldera and the iconic Bishop Tuff. Some of the field trips focus on volcanic eruptive and emplacement processes, calling attention to the fact that the western United States provides opportunities to examine a wide range of volcanological phenomena at many scales.

The 2017 Scientific Assembly of the International Association of Volcanology and Chemistry of the Earth's Interior (IAVCEI) in Portland, Oregon, marks the first time that the U.S. volcanological community has hosted this quadrennial meeting since 1989, when it was held in Santa Fe, New Mexico. The 1989 field-trip guides are still widely used by students and professionals alike. This new set of field guides is similarly a legacy collection that summarizes decades of advances in our understanding of magmatic and tectonic processes of volcanic western North America.

The field of volcanology has flourished since the 1989 IAVCEI meeting, and it has profited from detailed field investigations coupled with emerging new analytical methods. Mapping has been enhanced by plentiful major- and trace-element whole-rock and mineral data, technical advances in radiometric dating and collection of isotopic data, GPS (Global Positioning System) advances, and the availability of lidar (light detection and ranging) imagery. Spectacularly effective microbeam instruments, geodetic and geophysical data collection and processing, paleomagnetic determinations, and modeling capabilities have combined with mapping to provide new information and insights over the past 30 years. The collective works of the international community have made it possible to prepare wholly new guides to areas across the western United States. These comprehensive field guides are available, in large part, because of enormous contributions from many experienced geologists who have devoted entire careers to their field areas. Early career scientists are carrying forward and refining their foundational work with impressive results.

Our hope is that future generations of scientists as well as the general public will use these field guides as introductions to these fascinating areas and will be enticed toward further exploration and field-based research.

Michael Dungan, University of Oregon Judy Fierstein, U.S. Geological Survey Cynthia Gardner, U.S. Geological Survey Dennis Geist, National Science Foundation

Anita Grunder, Oregon State University John Wolff, Washington State University

Field-trip committee, IAVCEI 2017 


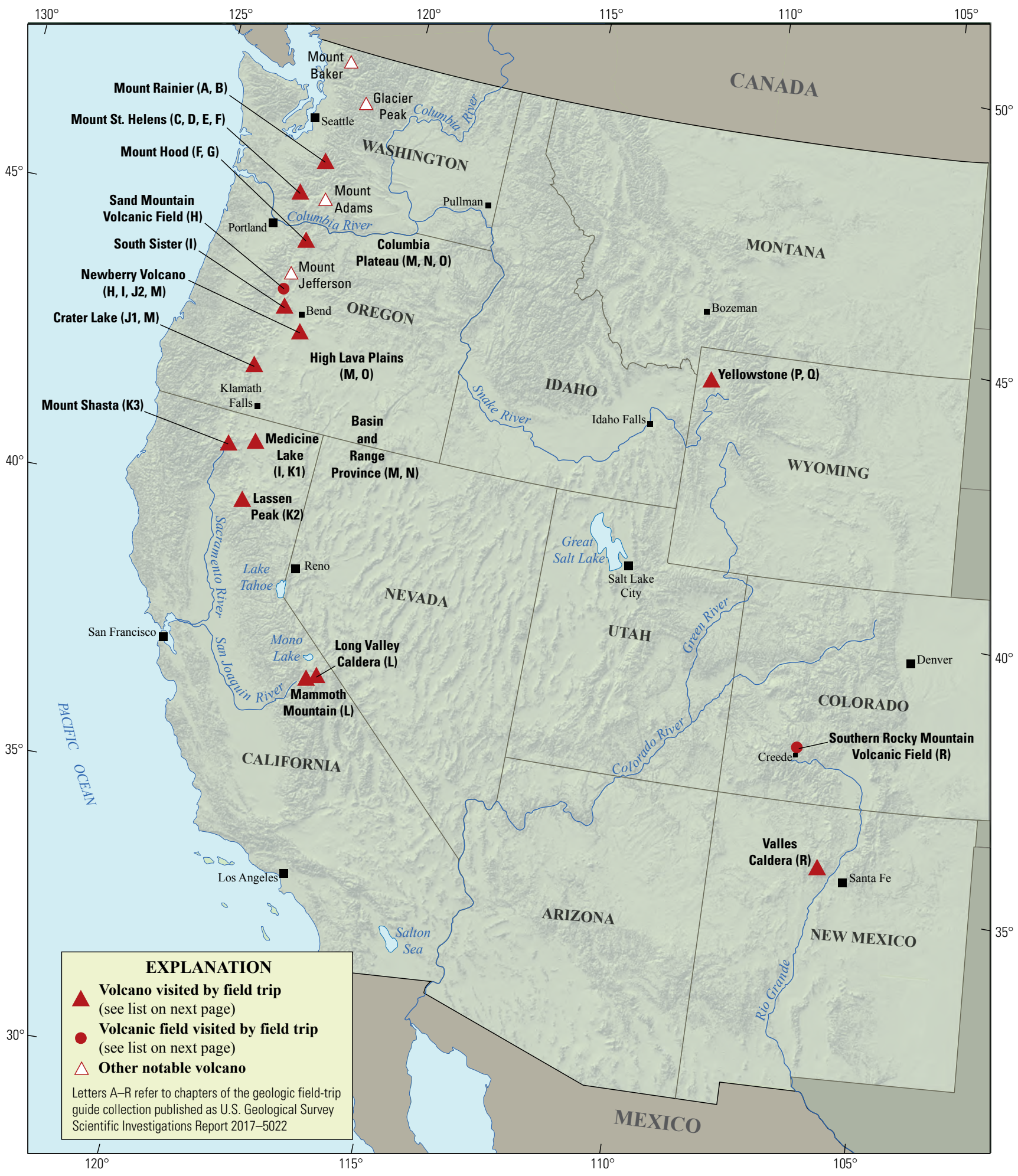

Map of the western United States showing volcanoes and volcanic fields visited by geologic field trips scheduled in conjunction with the 2017 meeting of the International Association of Volcanology and Chemistry of the Earth's Interior (IAVCEI) in Portland, Oregon, and available as chapters in U.S. Geological Survey Scientific Investigations Report 2017-5022. Shaded-relief base from U.S. Geological Survey National Elevation

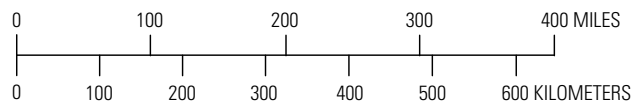
Dataset 30-meter digital elevation model data. 


\author{
Chapter \\ letter \\ Title \\ A \\ Field-Trip Guide to Volcanism and Its Interaction with Snow and Ice at Mount Rainier, \\ Washington \\ B \\ Field-Trip Guide to Subaqueous Volcaniclastic Facies in the Ancestral Cascades Arc in \\ Southern Washington State-The Ohanapecosh Formation and Wildcat Creek Beds \\ C \\ Field-Trip Guide for Exploring Pyroclastic Density Current Deposits from the May 18, 1980, \\ Eruption of Mount St. Helens, Washington \\ D Field-Trip Guide to Mount St. Helens, Washington—An Overview of the Eruptive History \\ and Petrology, Tephra Deposits, 1980 Pyroclastic Density Current Deposits, and the \\ Crater \\ $E$ \\ $\mathrm{F}$ \\ G \\ H \\ Field-Trip Guide to Mount St. Helens, Washington—Recent and Ancient Volcaniclastic \\ Processes and Deposits \\ Geologic Field-Trip Guide of Volcaniclastic Sediments from Snow- and Ice-Capped \\ Volcanoes-Mount St. Helens, Washington, and Mount Hood, Oregon \\ Field-Trip Guide to Mount Hood, Oregon, Highlighting Eruptive History and Hazards \\ Field-Trip Guide to Mafic Volcanism of the Cascade Range in Central Oregon-A \\ Volcanic, Tectonic, Hydrologic, and Geomorphic Journey \\ Field-Trip Guide to Holocene Silicic Lava Flows and Domes at Newberry Volcano, \\ Oregon, South Sister Volcano, Oregon, and Medicine Lake Volcano, California \\ Overview for Geologic Field-Trip Guides to Mount Mazama, Crater Lake Caldera, and \\ Newberry Volcano, Oregon \\ Geologic Field-Trip Guide to Mount Mazama and Crater Lake Caldera, Oregon \\ Field-Trip Guide to the Geologic Highlights of Newberry Volcano, Oregon \\ Overview for Geologic Field-Trip Guides to Volcanoes of the Cascades Arc in Northern \\ California \\ Geologic Field-Trip Guide to Medicine Lake Volcano, Northern California, Including Lava \\ Beds National Monument \\ Geologic Field-Trip Guide to the Lassen Segment of the Cascades Arc, Northern \\ California \\ Geologic Field-Trip Guide to Mount Shasta Volcano, Northern California \\ Geologic Field-Trip Guide to Long Valley Caldera, California \\ Field-Trip Guide to a Volcanic Transect of the Pacific Northwest \\ Field-Trip Guide to the Vents, Dikes, Stratigraphy, and Structure of the Columbia River \\ Basalt Group, Eastern Oregon and Southeastern Washington \\ Field-Trip Guide to Flood Basalts, Associated Rhyolites, and Diverse Post-Plume \\ Volcanism in Eastern Oregon \\ Field-Trip Guide to the Volcanic and Hydrothermal Landscape of Yellowstone Plateau, \\ Montana and Wyoming \\ Field-Trip Guide to the Petrology of Quaternary Volcanism on the Yellowstone Plateau, \\ Idaho and Wyoming \\ Field-Trip Guide to Continental Arc to Rift Volcanism of the Southern Rocky \\ Mountains-Southern Rocky Mountain, Taos Plateau, and Jemez Volcanic Fields of \\ Southern Colorado and Northern New Mexico
}




\section{Contributing Authors}

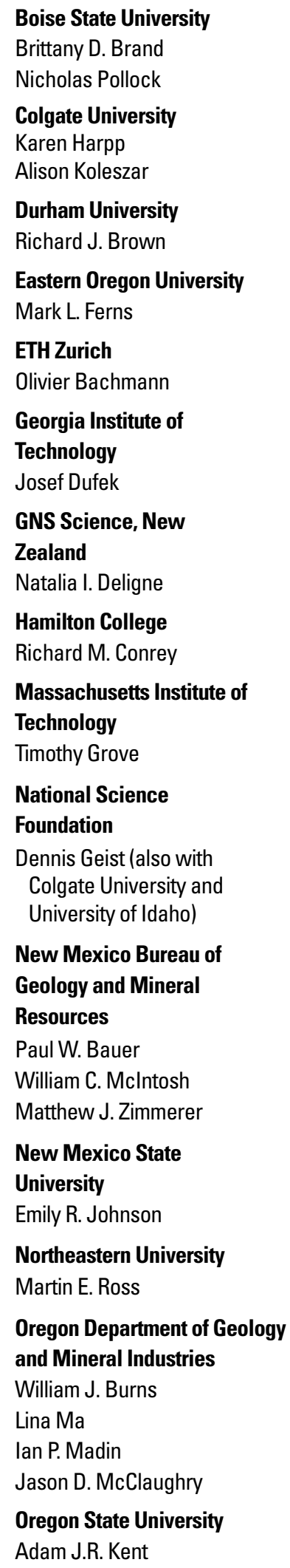

\author{
Portland State University \\ Jonathan H. Fink (also with \\ University of British Columbia) \\ Martin J. Streck \\ Ashley R. Streig
}

San Diego State University
Victor E Camp

Smithsonian Institution

Lee Siebert

Universidad Nacional

Autónoma de San Luis Potosi

Damiano Sarocchi

University of California, Davis

Kari M. Cooper

University of Liverpool

Peter B. Kokelaar

University of Northern

Colorado

Steven W. Anderson

University of Oregon

Ilya N. Binderman

Michael A. Dungan

Daniele Mckay (also with Oregon State University and Oregon State University, Cascades)

University of Portland Kristin Sweeney

University of Tasmania

Martin Jutzeler

Jocelyn McPhie

University of Utah

Jamie Farrell

U.S. Army Corps of

Engineers

Keith I. Kelson

\section{U.S. Forest Service}

Gordon E. Grant (also with Oregon State University)

\section{U.S. Geological Survey}

Charles R. Bacon

Andrew T. Calvert

Christine F. Chan

Robert L. Christiansen

Michael A. Clynne

Michael A. Cosca

Julie M. Donnelly-Nolan

Benjamin J. Drenth
William C. Evans

Judy Fierstein

Cynthia A. Gardner

V.J.S. Grauch

Christopher J. Harpel

Wes Hildreth

Richard P. Hoblitt

Robert A. Jensen

Peter W. Lipman

Jacob B. Lowenstern

Jon J. Major

Seth C. Moran

Lisa A. Morgan

Leah E. Morgan

L.J. Patrick Muffler

Jim O'Connor

John S. Pallister

Thomas C. Pierson

Joel E. Robinson

Juliet Ryan-Davis

Kevin M. Scott

William E. Scott

Wayne (Pat) Shanks

David R. Sherrod

Thomas W. Sisson

Mark Evan Stelten

Weston Thelen

Ren A. Thompson

Kenzie J. Turner

James W. Vallance

Alexa R. Van Eaton

Jorge A. Vazquez

Richard B. Waitt

Heather M. Wright

U.S. Nuclear Regulatory

Commission

Stephen Self (also with University of California, Berkeley)

Washington State University Joseph R. Boro

Owen K. Neill

Stephen P. Reidel

John A. Wolff

\section{Acknowledgments}

Juliet Ryan-Davis and Kate Sullivan created the overview map, and Vivian Nguyen created the cover design for this collection of field-trip guide books. The field trip committee is grateful for their contributions. 


\section{Contents}

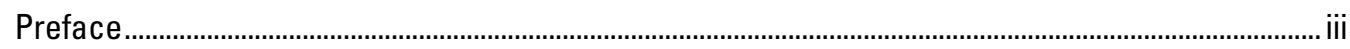

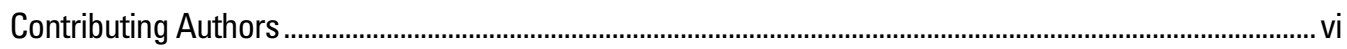

Overview for Geologic Field-Trip Guides to Mount Mazama, Crater Lake Caldera, and Newberry

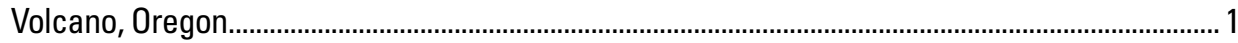

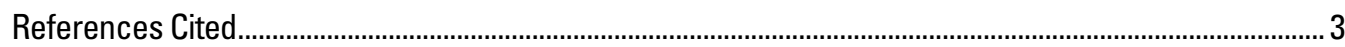

\section{Figure}

1. Shaded-relief map of central Oregon showing Crater Lake and Newberry Volcano as well as place names and principle roads relevant to IAVCEI 2017 field trip ......................................... 2 



\title{
Overview for Geologic Field-Trip Guides to Mount Mazama, Crater Lake Caldera, and Newberry Volcano, Oregon
}

\author{
By Charles R. Bacon, Julie M. Donnelly-Nolan, Robert A. Jensen, and Heather M. Wright
}

These field-trip guides were written for the occasion of the International Association of Volcanology and Chemistry of the Earth's Interior (IAVCEI) quadrennial scientific assembly in Portland, Oregon, in August 2017. The guide to Mount Mazama and Crater Lake caldera is an updated and expanded version of the guide (Bacon, 1989) for part of an earlier IAVCEI trip to the southern Cascade Range. The guide to Newberry Volcano describes the stops included in the 2017 field trip. Locations of the two volcanoes are shown on figure 1. Crater Lake and Newberry are the two best-preserved and most recent calderas in the Cascades Volcanic Arc. Although located in different settings in the arc, with Crater Lake on the arc axis and Newberry in the rear-arc, both volcanoes are located at the intersection of the arc and the northwest corner region of the extensional Basin and Range Province.

The overarching theme that connects the two volcanic centers is possession of similar-sized 6- to 10-kilometer $(\mathrm{km})$-diameter collapse calderas, common in volcanic arcs but relatively small in the spectrum of caldera size and erupted volume (Smith, 1979; Lipman, 1997). Few Quaternary calderas are known or implied to exist in the Cascades Arc (Hildreth, 2007; Nathenson and others, 2012). Youngest is Crater Lake caldera that collapsed $\sim 7,700$ years ago during the $\sim 50$ cubic kilometer $\left(\mathrm{km}^{3}\right)$ climactic eruption of Mount Mazama, the volcanic edifice at Crater Lake (Bacon and Lanphere, 2006). Newberry caldera, formed $\sim 75$ thousand years ago (ka) (Donnelly-Nolan and others, 2011) during a $\leq 50 \mathrm{~km}^{3}$ explosive eruption, is the youngest of three calderas at Newberry. Two additional calderas nearby are inferred on the basis of ash-flow tuffs erupted $\sim 300$ and $\sim 170 \mathrm{ka}$, northwest of Newberry Volcano from the arc axis where the Three Sisters volcanoes sit atop the arc crest. Another caldera dates from $\sim 180 \mathrm{ka}$ at the Medicine Lake rear-arc volcano (Donnelly-Nolan, 2010) 100 miles $(160 \mathrm{~km})$ south of Crater Lake, also where Basin and Range extension impinges on the arc.

Both Mount Mazama and Newberry volcanoes have existed since at least $400 \mathrm{ka}$ and have erupted a diversity of magma types. Mazama eruptive products range from basaltic andesite to rhyodacite (Bacon and Lanphere, 2006), whereas Newberry lava compositions range from basalt to rhyolite (Jensen and others, 2009). Abundance of andesite and dacite resulted in a Mazama edifice composed of overlapping stratocones whereas a dominance of basaltic andesite led to more shield-like Newberry. The presence of mafic eruptive products with diverse geochemical signatures in the vicinity of both volcanoes is evidence for nearly dry and more hydrous mantle melt-generation processes (for example, high-alumina olivine tholeiite [HAOT] and typical arc basalt/basaltic andesite). Subduction-related flux melting dominates at Crater Lake (Bacon, 1990) but is also an important process at Newberry (Till and others, 2013; Mandler and others, 2014). McCrory and others (2012) project the depth to the Juan de Fuca slab to be $\sim 75 \mathrm{~km}$ beneath Mazama and $\sim 100 \mathrm{~km}$ under Newberry, although few recorded earthquake hypocenters constrain slab depth in this part of the arc. Nevertheless, both volcanoes illustrate aspects of arc volcanism and are worthy subjects for IAVCEI and other geological field excursions. 


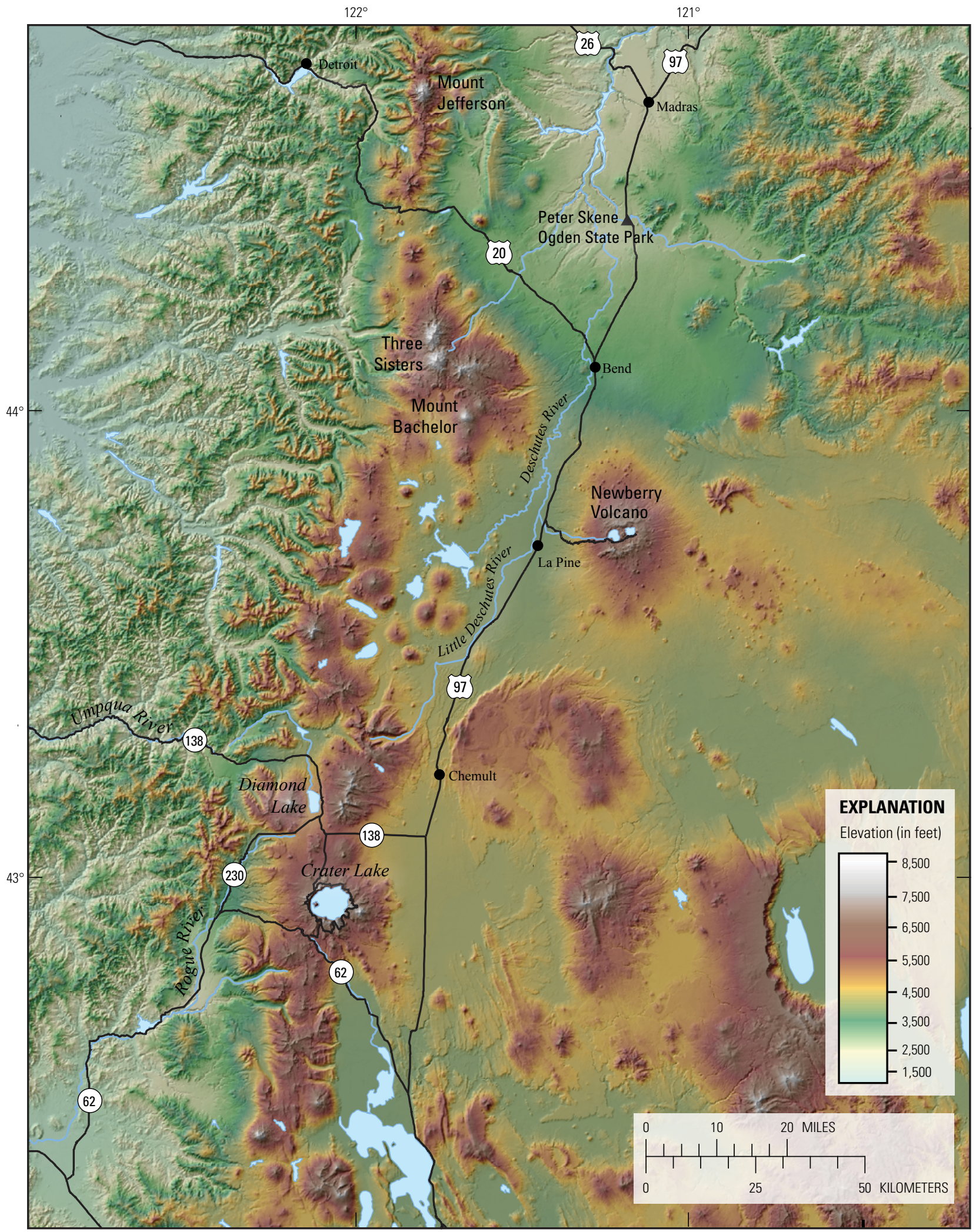

Hillshade base derived from U.S. Geological Survey National elevation dataset 30-meter digital elevation model

Figure 1. Shaded-relief map of central Oregon showing Crater Lake and Newberry Volcano as well as place names and principle roads relevant to IAVCEI 2017 field trip. 


\section{References Cited}

Bacon, C.R., 1989, Mount Mazama and Crater Lake caldera, Oregon, in Chapin, C.E., and Zidek, J., eds., Field excursions to volcanic terranes in the western United States, Volume IICascades and Intermountain West: New Mexico Bureau of Mines and Mineral Resources Memoir 47, p. 203-211.

Bacon, C.R., 1990, Calc-alkaline, shoshonitic, and primitive tholeiitic lavas from monogenetic volcanoes near Crater Lake, Oregon: Journal of Petrology, v. 31, p. 135-166.

Bacon, C.R., and Lanphere, M.A., 2006, Eruptive history and geochronology of Mount Mazama and the Crater Lake region, Oregon: Geological Society of America Bulletin, v. 118, nos. 11-12, p. 1331-1359.

Donnelly-Nolan, J.M., 2010, Geologic map of Medicine Lake volcano, northern California: U.S. Geological Survey Scientific Investigations Map 2927, scale 1:50,000, https:// pubs.usgs.gov/sim/2927/.

Donnelly-Nolan, J.M., Stovall, W.K., Ramsey, D.W., Ewert, J.W., and Jensen, R.A., 2011, Newberry Volcano-Central Oregon's Sleeping Giant: U.S. Geological Survey Fact Sheet 2011-3145, 6 p., https://pubs.usgs.gov/fs/2011/3145/.

Hildreth, W., 2007, Quaternary magmatism in the CascadesGeologic perspectives: U.S. Geological Survey Professional Paper 1744, 125 p., https://pubs.usgs.gov/pp/pp1744/.

Jensen, R.A., Donnelly-Nolan, J.M., and Mckay, D., 2009, A field guide to Newberry Volcano, Oregon, in O'Connor, J.E., Dorsey, R.J., and Madin, I.P., eds., Volcanoes to Vineyards - Geologic Field Trips through the Dynamic Landscape of the Pacific Northwest: Geological Society of America Field Guide 15, p. 53-79, doi:10.1130/2009.fl d015(03).
Lipman, P.W., 1997, Subsidence of ash-flow calderasRelation to caldera size and magma-chamber geometry: Bulletin of Volcanology, v. 59, p. 198-218.

Mandler, B.E., Donnelly-Nolan, J.M., and Grove, T.L., 2014, Straddling the tholeiitic/calc-alkaline transitionThe effects of modest amounts of water on magmatic differentiation at Newberry Volcano, Oregon: Contributions to Mineralogy and Petrology, v. 168:1066, 25 p., doi:10.1107/s00410-014-1066-7.

McCroy, P.A., Blair, J.L., Waldhauser, F., and Oppenheimer, D.H., 2012, Juan de Fuca slab geometry and its relation to Wadati-Benioff zone seismicity: Journal of Geophysical Research, v. 117, B09306, 23 p., doi:10.1029/2012JB009407.

Nathenson, M., Clynne, M.A, and Muffler, L.J.P., 2012, Eruption probabilities for the Lassen Volcanic Center and regional volcanism, northern California, and probabilities for large explosive eruptions in the Cascade Range: U.S. Geological Survey Scientific Investigations Report 20125176-B, 23 p., http://pubs.usgs.gov/sir/2012/5176/b/.

Smith, R.L., 1979, Ash-flow magmatism, in Chapin, C.E., and Elston, W.E., eds., Ash-flow tuffs: Geological Society of America Special Paper 180, p. 5-27.

Till, C.B., Grove, T.L., Carlson, R.W., Donnelly-Nolan, J.M., Fouch, M.J., Wagner, L.S., and Hart, W.K., 2013, Depths and temperatures of asthenopheric melting and the lithosphere-asthenosphere boundary in the southern Cascades arc and back-arc: Geochemistry, Geophysics, Geosystems, v. 14 , no. 4, p. 864-879. 
